Original Research Paper

\title{
The Effect of Fermentation Length and Dosage of Liquid of Organic Fertilizer Banana Peel on the Growth of Red Spinach (Amaranthus Tricolor L.)
}

\author{
Nurul Fadhilah $^{1}$, Prapti Sedijani ${ }^{1^{*}}$, I Gde Mertha ${ }^{1}$ \\ ${ }^{1}$ Program Studi Pendidikan Biologi, Jurusan PMIPA FKIP Universitas Mataram, Indonesia
}

\author{
Article History \\ Received : June $28^{\text {th }}, 2021$ \\ Revised : August $30^{\text {th }}, 2021$ \\ Accepted : September 15 $5^{\text {th }}, 2021$ \\ Published : September $30^{\text {th }}, 2021$ \\ *Corresponding Author: \\ Prapti Sedijani, \\ Pendidikan Biologi, FKIP Unram, \\ Mataram, Indonesia \\ Email: \\ praptisedijani@unram.ac.id
}

\begin{abstract}
Fertilizer substitutes elements that have been used by plants. There are two available fertilizers, inorganic and organic fertilizers. Long-term use of inorganic fertilizers on a land negatively affects the crop and the soil fertility, hence, the organic one is a better choice. This study aims to determine the effect of liquid organic fertilizer of banana peels on the growth of red spinach and determine the best treatment for red spinach growth. This study used a Completely Randomized Design consisted of 2 factors (dosage of POC banana peel and length of fermentation time). Each has 4 levels, 3 replicates. The results of data analysis using ANOVA test show that the treatment of fermentation length and dosage of POC banana peel increase growth parameters of red spinach include plant height, leaf number, leaf area, fresh weight, and dry weight, while the interaction treatment of fermentation length and dosage of POC banana peel affects almost all growth parameters, except for the leaf area parameter that shows no interaction. DMRT ( $\alpha$ 5\%) test shows that the best combination treatment for plant height and fresh weight is a dosage of $8 \mathrm{ml}$ POC of banana peel that have been fermented for 15 days, and the best treatment for leaf number and dry weight is a dosage of $8 \mathrm{ml}$ POC of banana peel that have been fermented for 10 days.
\end{abstract}

Keywords: Banana Peels POC, Fermentation Lenght, Dosage, Growth of Red spinach

\section{Pendahuluan}

Produktivitas lahan pertanian Indonesia menurun, karena adanya alih fungsi untuk nonpertanian dan penggunaan pupuk yang tidak tepat. Pupuk merupakan aspek penting bagi kesuburan tanah yang memberikan unsur-unsur yang dibutuhkan tanaman. Pupuk terbagi menjadi dua jenis yaitu pupuk organik dan pupuk anorganik. Pupuk anorganik pupuk adalah olahan mineral oleh pabrik menjadi bahan kimia yang mudah terserap oleh tanaman. Pupuk ini memiliki beberapa kelebihan antara lain mudah didapat, mudah penanganya, komposis dan dosis pemakainya dapat diatur sesuai kebutuhan tanaman. Disisi lain pupuk anorganik mempunyai dampak negative bagi kesuburan tanah, antara lain jika pupuk ini dipakai secara terus menerus dalam jangka jangka panjang dapat mengubah struktur fisika, kimia dan biologi tanah1'TYUJ (Hadisuwinto, 2012: Hartini et al., 2019; Lingga dan Marsono, 2008; Pangaribuan et al., 2017). Selanjutnya jika pemakaiannya berlebihan, dapat mencemari perairan yang mengganggu ekosistem perairan, misalnya peledakan jumlah alga.

Berbeda dengan pupuk anorganik, pupuk organik merupakan hasil pelapukan materi makhluk hidup seperti sisa-sisa kotoran hewan/manusia dan tanaman yang sudah mati. Banyak mikroorganisme yang terlibat dalam dekomposisi materi organic ini, sehaingga memperkaya deversitas mikroba maupun makroflora dalam tanah yang akan 
memeparbaiki struktur fisika, kimia dan biologi tanah, disamping mengembalikan unsur hara ke dalam tanah. Dengan demikian, pupuk organik menyuburkan tanah yang ramah ramah lingkungan.

Kendala dari penggunaan pupuk ini anatara lain, efeknya yang lebih lambat, diperlukan jumlah yang banyak guna mencukupi unsur hara per tanaman, sehingga penanganya tidak sesederhana pupuk anorganik. Namun demikian, pupuk organik bisa berbentuk padat atau cair, bentuk yang cair ini tentunya lebih mudah pengaplikasiaannya dibanding yang padat, dan ternyata disebutkan dalam beberapa literatur (Kurniawati et al., 2015; Marjenah et al., 2017; Raksun, 2018; Sutanto, 2002) pupuk yang cair ini, materi organiknya sudah terurai sehingga lebih mudah diserap oleh tanaman.

Saat ini, masyarakat mengangap kulit pisang adalah limbah yang tidak dapat digunakan lagi, sementara Susetya (2012) menyatakan bahwa kulit pisang ini mencapai sepertiga bagian dari buah pisang sehingga jika tidak dikelola dengan baik, kulit pisang berpotensi sebagai limabh pencemar lingkungan, terutama diarea dimana pisang menjadi komoditi dan diolah lebih lanjut menjadi produk turunan yang dikomersialkan.

Di dalam kulit pisang terkandung unsur makro antara lain $\mathrm{N}, \mathrm{P}$ dan $\mathrm{K}$ serta unsur mikro seperti, $\mathrm{Ca}, \mathrm{Mg}, \mathrm{Na}, \mathrm{Ca}$ dan $\mathrm{Zn}$ (.......) yang sangat berguna bagi pertumbuhan, perkembangan serta kebugaran tanaman. Unsur nitrogen berperan untuk merangsang pertumbuhan secara keseluruhan, serta berperan penting dalam pembentukan hijau daun yang sangat berguna dalam proses fotosintesis. Selain itu, kandungan protein, kalsium, fosfor, magnesium, sodium dan sulfur menjadikan kulit pisang berpotensi sebagai bahan pupuk organik (Manis, et al., 2017; Nasution, 2014; Nasrun, et al., 2016).

Kandungan nutrisi dari pupuk organic yang berariasi sehingga memerlukan perhatian untuk penggunaanya. Beberapa faktor seperti jenis organik yang digunakan dan lama fermentasi mempengrauhi nutrisi yang dikandungnya. Hal ini terjadi karena jika terlalu cepat banyak materi organic belum terurai dengan baik, namun fermentasi yang terlalu lama menyebabkan banyaknya materi organic yang hilang/dimanfaatkan oleh mikroorganisme fermenter atau organisme lainya. Dengan demikian sesuai pernyataan (Nur, et al., 2016; Wijaksono, et al., 2016) bahwa lama fermentasi mempengaruhi kwalitas pupuk organic cair.

Dari uraian diatas, maka peneliti mencoba untuk mengetahui kaitan antara fermentasi kulit pisang dengan pertumbuhan tanaman, dalam hal ini bayam merah. Dipilihnya bayam merah dalam penelitian ini karena beberapa alasan yang dikemukakan di Alinea berikut.

Selain warnanya yang cantik, bayam merah juga memiliki kandungan gizi antara lain protein, vitamin $\mathrm{A}, \mathrm{B}, \mathrm{C}, \mathrm{K}$; mengandung beta caroten, karbohidrat dan lemak (Syariff et al, 2019). Lebih lanjut Syarif menjelaskan bahwa bayam merah juga mengandung flavonoid, alkaloid dan lutein yang baik untuk kesehatan, namun penulis tersebut menemukan bahwa dalam bayam merah/hijau terkandung kristal oxalate yang cukup tinggi. Dengan demikian, jumlah penggunaanya yang perlu diwaspadai. Meskipun demikian, bayam merah masih mempunyai nilai ekonomi yang patut dipertimbangkan dan meningkatkan produksi bayam merah masih perlu dilakukan dan antara lain dengan pemupukan.

Dari uraian diatas, penelitian ini dilakukan dengan judul seperti tertera diatas. Adapun tujuan penelitian ini adalah untuk mengetahui (1) pengaruh lama fermentasi dan dosis pupuk organik cair kulit pisang terhadap pertumbuhan tanaman bayam merah, (2) lama fermentasi pupuk organik cair kulit pisang yang terbaik untuk meningkatkan pertumbuhan tanaman bayam merah, (3) dosis pupuk organik cair kulit pisang yang paling baik untuk meningkatkan pertumbuhan tanaman bayam merah, (4) lama fermentasi dan dosis pupuk organik cair kulit pisang yang terbaik untuk meningkatkan pertumbuhan tanaman bayam merah, (5) interaksi antara dosis dan lama fermentasi pupuk organik cair kulit pisang terhadap pertumbuhan tanaman bayam merah.

\section{Bahan dan Metode}

Parameter pertumbuhan yang diukur adalah tinggi tanaman, jumlah daun, luas daun, berat basah, dan berat kering. Bahan-bahan yang digunakan dalam penelitian ini adalah air, tanah subur, sekam, benih bayam merah, kulit pisang, polibag ukuran 30x30 cm, EM4, gula pasir, 
kertas label, plastik, dan kertas aluminium foil. Alat-alat yang digunakan dalam penelitian ini adalah sekop, blender, digital tester meter, gelas ukur, tong plastik, oven, pengaduk kayu, pengayak tanah, penggaris, pisau, ember bak plastik, timbangan analitik, termometer, timbangan manual, dan saringan (kain halus).

Tahap pelaksanaan penelitian ini adalah: (1) membuat POC dari kulit pisang yang difermentasikan selama $0,5,10$ dan 15 hari, (2) menyiapkan media tanam dengan mencampur sekam dan tanah dengan perbandingan volume $2: 1$, (3) menyeleksi benih yang baik, (3) menanam benih sebanyak 8 benih per polibag, (4) melakukan penjarangan setelah tanaman tumbuh dengan jumlah daun sebanyak 2 helai, (5) melakukan pemeliharaan dengan penyiraman dan penyiangan, (6) memberikan POC kulit pisang sesuai dosis perlakuan dengan lama fermentasi masing-masing waktu fermentasi dengan interval pemberian satu kali seminggu, (7) mengukur $\mathrm{pH}$ tanah dan suhu lingkungan, (8)mengukur parameter pertumbuhan tanaman.

Adapun teknik pengukuran pertumbuhan tanaman sawi sendok sebagai berikut:

\section{Tinggi tanaman}

Tinggi tanaman diukur menggunakan penggaris, mulai dari pangkal batang yang paling dekat dengan akar hingga ujung daun terpanjang ditarik ke atas.

2. Jumlah daun

Jumlah daun yang dihitung adalah daun yang telah membuka sempurna.

3. Luas daun

Pengukuran luas daun dilakukan dengan metode gravimetric. Menurut Irwan \& Fiky (2017), luas daun dapat dihitung dengan menggunakan rumus:

$$
\text { Luas Daun }=\frac{\text { Bobot replika daun }}{\text { Bobot kertas } 10 \mathrm{~cm} \times 10 \mathrm{~cm}} \times 100 \mathrm{~cm}^{2}
$$

4. Berat basah

Tanaman dibersihkan dari tanah yang melekat menggunakan air mengalir, selanjutnya dikering anginkan selama 5 menit lalu ditimbang semua bagian tanaman kecuali akar.

5. Berat kering

Tanaman dibungkus terlebih dahulu menggunakan kertas alumunium foil kemudian di oven selama 24 jam pada suhu $70^{\circ} \mathrm{C}$. Setelah di oven, sampel tersebut ditimbang menggunakan timbangan analitik.

Rancangan penelitian yang digunakan adalah rancangan acak lengkap terdiri atas 2 faktor yang masing-masing memiliki 4 taraf pemupukan dan diulang sebanyak 3 kali. Faktor pertama adalah dosis pupuk organik cair kulit pisang yaitu $A_{0}=0 \mathrm{ml} / 100 \mathrm{ml}$ air, $A_{4}=4 \mathrm{ml} / 100$ $\mathrm{ml}$ air, $\mathrm{A}_{6}=6 \mathrm{ml} / 100 \mathrm{ml}$ air dan $\mathrm{A}_{8}=8 \mathrm{ml} / 100 \mathrm{ml}$ air. Faktor kedua adalah lama fermentasi POC yaitu $\mathrm{B}_{0}=0$ hari, $\mathrm{B}_{5}=5$ hari, $\mathrm{B}_{10}=10$ hari dan $\mathrm{B}_{15}$ $=15$ hari. Setiap kombinasi perlakuan sebagai berikut:

Tabel 1. Rancangan Penelitian

\begin{tabular}{|c|c|c|c|c|}
\hline Perlakuan & A0 & A4 & A6 & A8 \\
\hline B0 & A0B0 & A4B0 & A6B0 & A8B0 \\
\hline B5 & A0B5 & A4B5 & A6B5 & A8B5 \\
\hline B10 & A0B10 & A4B10 & A6B10 & A8B10 \\
\hline B15 & A0B15 & A4B15 & A6B15 & A8B15 \\
\hline
\end{tabular}

Pupuk diberikan sesuai dosis perlakuan mulai dari hari ke 14 setelah tanam, seminggu sekali pada pagi hari selama 3 minggu.

Data kuantitatif hasil pengukuran parameter pertumbuhan tanaman bayam merah dianalisis dengan menggunakan uji ANOVA (Analysis of Variance) dua arah. Uji lanjut yang digunakan adalah Ducan's Multiple Range Test (DMRT).

\section{Hasil dan Pembahasan}

\section{Kondisi Lingkungan}

Suhu lingkungan $\left({ }^{\circ} \mathrm{C}\right)$ dan $\mathrm{pH}$ tanah pada penelitian ini bervariasi. Suhu lingkungan $\left({ }^{\circ} \mathrm{C}\right)$ tempat penelitian diukur pada pagi hari sekitar pukul 09.00 WITA dan sore hari pada pukul 17.00 WITA. Suhu lingkungan pada pagi hari lebih tinggi dibandingkan suhu lingkungan pada sore hari, dimana suhu lingkungan tempat penelitian pada pagi hari berkisar $30^{\circ} \mathrm{C}-33^{\circ} \mathrm{C}$, sedangkan suhu lingkungan tempat penelitian pada sore hari berkisar $28^{\circ} \mathrm{C}-31^{\circ} \mathrm{C}$.

Kondisi $\mathrm{pH}$ tanah diukur pada pagi hari. Rata-rata kondisi $\mathrm{pH}$ tanah pada penelitian ini berkisar 5,0 - 6,5. Rata-rata kondisi $\mathrm{pH}$ tanah pada minggu pertama sampai minggu kedua $\mathrm{pH}$ tanah berkisar 5,0 - 6,7. Selanjutnya minggu ketiga $\mathrm{pH}$ tanah semua perlakuan berkisar 6,0 - 
6,5, kecuali pada perlakuan A0B0. Sedangkan rata-rata $\mathrm{pH}$ tanah pada minggu keempat sampai minggu kelima mengalami kenaikan $\mathrm{pH}$ tanah. Rata-rata $\mathrm{pH}$ tanah untuk perlakuan pada minggu ketiga sampai dengan minnggu kelima berkisar pH 5,7-6,5.

\section{Tinggi Tanaman}

Pengukuran tinggi tanaman bayam merah dilakukan pada minggu terakhir yakni 31 hari setelah tanam (HST) menggunakan penggaris dengan satuan centimeter. Hasil uji DMRT 5\% dosis dan lama fermentasi POC kulit pisang terhadap tinggi tanaman disajikan pada Tabel 2.

Tabel 2. Hasil Uji DMRT 5\% Dosis dan Lama Fermentasi POC Kulit Pisang terhadap Tinggi Tanaman Bayam Merah

\begin{tabular}{cc}
\hline Perlakuan Dosis & Hasil Uji DMRT \\
\hline A0 & $23,99 \mathrm{~d}$ \\
A4 & $24,68 \mathrm{c}$ \\
A6 & $31,08 \mathrm{~b}$ \\
A8 & $33,27 \mathrm{a}$ \\
\hline Lama Fermentasi & Hasil Uji DMRT \\
\hline B0 & $26,19 \mathrm{c}$ \\
B5 & $24,64 \mathrm{c}$ \\
B10 & $26,99 \mathrm{~b}$ \\
B15 & $33,14 \mathrm{a}$ \\
\hline
\end{tabular}

Aplikasi POC kulit pisang pada dosis A8 (8 $\mathrm{ml} \mathrm{POC} / 100 \mathrm{ml}$ air) dan lama fermentasi B15 (15 hari) menunjukkan hasil paling tinggi dari semua perlakuan dalam penelitian ini dan berbeda nyata dengan perlakuan lainnya (Tabel 2). Berdasarkan hasil tersebut, dosis A8 dan lama fermentasi B15 merupakan perlakuan terbaik pada penelitian ini. Hasil uji perbedaan antar kombinasi terhadap tinggi tanaman bayam merah disajikan pada Tabel 3.

Tabel 3. Hasil Uji Perbedaan antar Kombinasi terhadap Tinggi Tanaman Bayam Merah

\begin{tabular}{ccc}
\hline Kode & $\begin{array}{c}\text { Dosis Perlakuan } \\
\text { (per 100 ml air) }\end{array}$ & $\begin{array}{c}\text { Rata-Rata Tinggi } \\
\text { Tanaman }(\mathbf{c m})\end{array}$ \\
\hline A0B0 & 0 mL 0 Hari POC & $24,0 \mathrm{abc}$ \\
A4B0 & 4 mL 0 Hari POC/ & $22,6 \mathrm{a}$ \\
A6B0 & $6 \mathrm{~mL}$ 0 Hari POC & $27,4 \mathrm{bcde}$ \\
A8B0 & $8 \mathrm{~mL}$ 0 Hari POC & $32,9 \mathrm{f}$ \\
A0B5 & 0 mL 5 Hari POC & $26,2 \mathrm{abcde}$ \\
A4B5 & 4 mL 5 Hari POC & $23,7 \mathrm{ab}$ \\
A6B5 & 6 mL 5 Hari POC & $28,9 \mathrm{de}$ \\
A8B5 & $8 \mathrm{~mL}$ 5 Hari POC & $29,7 \mathrm{ef}$ \\
A0B10 & 0 mL 10 Hari POC & $26,7 \mathrm{bcde}$ \\
\hline
\end{tabular}

\begin{tabular}{ccc}
\hline Kode & $\begin{array}{c}\text { Dosis Perlakuan } \\
\text { (per 100 ml air) }\end{array}$ & $\begin{array}{c}\text { Rata-Rata Tinggi } \\
\text { Tanaman }(\mathbf{c m})\end{array}$ \\
\hline A4B10 & 4 mL 10 Hari POC & $28,4 \mathrm{de}$ \\
A6B10 & 6 mL 10 Hari POC & $25,6 \mathrm{abcd}$ \\
A8B10 & $8 \mathrm{~mL} \mathrm{10} \mathrm{Hari} \mathrm{POC}$ & $40,4 \mathrm{~g}$ \\
A0B15 & 0 mL 15 Hari POC & $27,8 \mathrm{cde}$ \\
A4B15 & 4 mL 15 Hari POC & $26,8 \mathrm{bcde}$ \\
A6B15 & 6 mL 15 Hari POC & $29,7 \mathrm{ef}$ \\
A8B15 & 8 mL 15 Hari POC & $46,1 \mathrm{~h}$ \\
\hline Keterangan: Angka yang diikuti oleh huruf yang sama \\
\multicolumn{3}{c}{ berarti berbeda tidak nyata pada taraf uji }
\end{tabular}

Tabel 3 menunjukkan bahwa bahwa perlakuan kombinasi A8B15 dengan nilai 4,16 berbeda nyata dengan semua kombinasi perlakuan dalam penelitian ini. Berdasarkan hasil uji ini, perlakuan kombinasi A8B15 merupakan perlakuan terbaik.

\section{Jumlah Daun}

Perhitungan jumlah daun dilakukan dengan pada minggu terakhir yakni 31 (HST) dengan cara menghitung daun yang telah terbuka secara sempurna. Hasil uji DMRT 5\% dosis dan lama fermentasi POC kulit pisang terhadap jumlah daun disajikan pada Tabel 4.

Tabel 4. Hasil Uji DMRT 5\% Dosis dan Lama Fermentasi POC Kulit Pisang terhadap Jumlah Daun Bayam Merah

\begin{tabular}{cc}
\hline Perlakuan Dosis & Hasil Uji DMRT \\
\hline A0 & $10,33 \mathrm{c}$ \\
A4 & $10,92 \mathrm{c}$ \\
A6 & $11,29 \mathrm{~b}$ \\
A8 & $12,15 \mathrm{a}$ \\
\hline Lama Fermentasi & Hasil Uji DMRT \\
\hline B0 & $9,83 \mathrm{c}$ \\
B5 & $10,77 \mathrm{~b}$ \\
B10 & $11,90 \mathrm{a}$ \\
B15 & $11,54 \mathrm{a}$ \\
\hline
\end{tabular}

Aplikasi POC kulit pisang pada dosis A8 ( $8 \mathrm{ml} \mathrm{POC/100} \mathrm{ml}$ air) menunjukkan nilai ratarata paling tinggi terhadap jumlah daun dan berbeda nyata dengan perlakuan lainnya (Tabel 4). Perlakuan lama fermentasi B10 (10 hari) dan B15 (15 hari) menunjukkan hasil yang tidak berbeda nyata, namun kedua perlakuan tersebut berbeda nyata dari perlakuan yang lain berdasarkan hasil uji DMRT 5\% (Tabel 4). Menurut Hanafiah (2016) jika terdapat lebih dari satu hasil yang tertinggi namun tidak berbeda nyata maka perlakuan terbaik yang direkomendasikan adalah yang memiliki nilai 
lebih rendah. Berdasarkan hasil tersebut, lama fermentasi B10 (10 hari) merupakan perlakuan optimum. Hasil uji perbedaan antar kombinasi terhadap jumlah daun bayam merah disajikan pada Tabel 5.

Tabel 5. Hasil Uji Perbedaan antar Kombinasi terhadap Jumlah Daun Bayam Merah

\begin{tabular}{ccc}
\hline Kode & $\begin{array}{c}\text { Dosis Perlakuan } \\
\text { (per 100 ml air) }\end{array}$ & $\begin{array}{c}\text { Rata-Rata } \\
\text { Jumlah Daun } \\
\text { (helai) }\end{array}$ \\
\hline A0B0 & 0 mL 0 Hari POC & $\begin{array}{c}8,3 \mathrm{a} \\
10,0 \mathrm{bc}\end{array}$ \\
A4B0 & 4 mL 0 Hari POC/ & $9,7 \mathrm{~b}$ \\
A6B0 & $6 \mathrm{~mL}$ 0 Hari POC & $11,3 \mathrm{cde}$ \\
A8B0 & 8 mL 0 Hari POC & $11,3 \mathrm{cde}$ \\
A0B5 & 0 mL 5 Hari POC & $10,7 \mathrm{bcd}$ \\
A4B5 & 4 mL 5 Hari POC & $12,3 \mathrm{ef}$ \\
A6B5 & 6 mL 5 Hari POC & $11,3 \mathrm{cde}$ \\
A8B5 & $8 \mathrm{~mL} 5$ Hari POC & $10,7 \mathrm{bcd}$ \\
A0B10 & 0 mL 10 Hari POC & $11,3 \mathrm{bcd}$ \\
A4B10 & $4 \mathrm{~mL}$ 10 Hari POC & $13,0 \mathrm{f}$ \\
A6B10 & $6 \mathrm{~mL}$ 10 Hari POC & $15,3 \mathrm{~g}$ \\
A8B10 & $8 \mathrm{~mL}$ 10 Hari POC & $11,3 \mathrm{cde}$ \\
A0B15 & 0 mL 15 Hari POC & $11,7 \mathrm{de}$ \\
A4B15 & $4 \mathrm{~mL} \mathrm{15} \mathrm{Hari} \mathrm{POC}$ & $12,7 \mathrm{ef}$ \\
A6B15 & $6 \mathrm{~mL} \mathrm{15} \mathrm{Hari} \mathrm{POC}$ & $13,0 \mathrm{f}$ \\
A8B15 & $8 \mathrm{~mL}$ 15 Hari POC &
\end{tabular}

Keterangan: Angka yang diikuti oleh huruf yang sama berarti berbeda tidak nyata pada taraf uji

Tabel 5 menunjukkan bahwa perlakuan kombinasi A8B10 dengan nilai 15,3 berbeda nyata dengan semua kombinasi perlakuan yang lain. Berdasarkan hasil tersebut, perlakuan kombinasi A8B10 merupakan perlakuan paling baik.

\section{Luas Daun}

Pengukuran luas daun dilakukan pada minggu terakhir yakni 31 hari setelah tanam (HST) dengan metode gravimetrik. Hasil uji DMRT 5\% dosis dan lama fermentasi POC kulit pisang terhadap luas daun disajikan pada Tabel 6.

Tabel 6. Hasil Uji DMRT 5\% Dosis dan Lama Fermentasi POC Kulit Pisang terhadap Luas Daun Bayam Merah

\begin{tabular}{cc}
\hline Perlakuan Dosis & Hasil Uji DMRT \\
\hline A0 & $22,59 \mathrm{~b}$ \\
A4 & $23,72 \mathrm{~b}$ \\
A6 & $23,82 \mathrm{a}$ \\
A8 & $25,36 \mathrm{a}$ \\
\hline Lama Fermentasi & Hasil Uji DMRT \\
\hline B0 & $21,98 \mathrm{c}$ \\
B5 & $22,76 \mathrm{~b}$
\end{tabular}
B10
25,76 a
B15
$23,58 \mathrm{~b}$

Aplikasi POC kulit pisang pada dosis A8 (8 ml POC/100 ml air) dan A6 (6 ml POC/100 ml air) menunjukkan nilai yang tidak berbeda nyata terhadap luas daun, namun kedua perlakuan ini berbeda nyata dengan perlakuan lainnya berdasarkan hasil uji DMRT 5\% (Tabel 6). Namun, perlakuan optimum ditunjukkan oleh A6. Perlakuan lama fermentasi dengan hasil paling baik terhadap luas daun ditunjukkan pada perlakuan B10 (Tabel 6).

Hasil uji ANOVA menunjukkan perlakuan interaksi antara dosis dan lama fermentasi tidak menunjukkan hasil yang berbeda nyata (Tabel 4.1), maka pada perlakuan ini tidak dilanjutkan uji DMRT sebab tidak ada perlakuan yang berbeda nyata.

\section{Berat Basah}

Pengukuran berat basah dilakukan pada minggu terakhir yakni 31 hari setelah tanam (HST) dengan cara menimbang tanaman menggunakan timbangan analitik. Hasil uji DMRT 5\% dosis dan lama fermentasi POC kulit pisang terhadap berat basah tanaman bayam merah disajikan pada Tabel 7.

Tabel 7. Hasil Uji DMRT 5\% Dosis dan Lama Fermentasi POC Kulit Pisang terhadap Berat Basah Bayam Merah

\begin{tabular}{cc}
\hline Perlakuan Dosis & Hasil Uji DMRT \\
\hline A0 & $10,20 \mathrm{c}$ \\
A4 & $18,86 \mathrm{~b}$ \\
A6 & $22,31 \mathrm{a}$ \\
A8 & $23,73 \mathrm{a}$ \\
\hline Lama Fermentasi & Hasil Uji DMRT \\
\hline B0 & $9,90 \mathrm{~d}$ \\
B5 & $14,69 \mathrm{c}$ \\
B10 & $23,36 \mathrm{~b}$ \\
B15 & $27,16 \mathrm{a}$ \\
\hline
\end{tabular}

Aplikasi POC kulit pisang pada dosis A8 $(8 \mathrm{ml} \mathrm{POC} / 100 \mathrm{ml}$ air $)$ dan A6 (6 ml POC/100 ml air) masing-masing menunjukkan hasil yang berbeda nyata dengan perlakuan A4 $(4 \mathrm{ml}$ POC/100 ml air) dan A0 (0 ml POC/100 ml air) terhadap berat basah (Tabel 7). Hasil uji DMRT 5\% menunjukkan bahwa perlakuan dosis A6 dan dosis A8 berbeda tidak nyata. Dengan demikian mengacu pada Hanafiah (2016), maka perlakuan terbaik adalah dosis A6. Sedangkan untuk 
perlakuan lama fermentasi B15 (15 hari) menunjukkan hasil paling tinggi dari semua perlakuan. Hasil uji perbedaan antar kombinasi terhadap berat basah tanaman bayam merah disajikan pada Tabel 8.

Tabel 8. Hasil Uji Perbedaan antar Kombinasi terhadap Berat Basah Bayam Merah

\begin{tabular}{ccc}
\hline Kode & $\begin{array}{c}\text { Dosis Perlakuan } \\
\text { (per 100 ml air) }\end{array}$ & $\begin{array}{c}\text { Rata-Rata Berat Basah } \\
\text { (gr) }\end{array}$ \\
\hline A0B0 & 0 mL 0 Hari POC & $23,0 \mathrm{a}$ \\
A4B0 & $4 \mathrm{~mL}$ 0 Hari POC/ & $33,2 \mathrm{~b} \mathrm{a}$ \\
A6B0 & $6 \mathrm{~mL}$ 0 Hari POC & $41,2 \mathrm{bcd}$ \\
A8B0 & $8 \mathrm{~mL}$ 0 Hari POC & $45,7 \mathrm{cde}$ \\
A0B5 & 0 mL 5 Hari POC & $48,6 \mathrm{cde}$ \\
A4B5 & $4 \mathrm{~mL} 5$ Hari POC & $47,1 \mathrm{cde}$ \\
A6B5 & $6 \mathrm{~mL} 5$ Hari POC & $55,9 \mathrm{e}$ \\
A8B5 & $8 \mathrm{~mL} 5$ Hari POC & $53,1 \mathrm{de}$ \\
A0B10 & 0 mL 10 Hari POC & $52,0 \mathrm{cde}$ \\
A4B10 & $4 \mathrm{~mL} \mathrm{10} \mathrm{Hari} \mathrm{POC}$ & $47,6 \mathrm{cde}$ \\
A6B10 & $6 \mathrm{~mL} \mathrm{10} \mathrm{Hari} \mathrm{POC}$ & $57,2 \mathrm{e}$ \\
A8B10 & $8 \mathrm{~mL} \mathrm{10} \mathrm{Hari} \mathrm{POC}$ & $54,6 \mathrm{e}$ \\
A0B15 & $0 \mathrm{~mL} \mathrm{15} \mathrm{Hari} \mathrm{POC}$ & $40,9 \mathrm{bc}$ \\
A4B15 & $4 \mathrm{~mL} \mathrm{15} \mathrm{Hari} \mathrm{POC}$ & $50,8 \mathrm{cde}$ \\
A6B15 & $6 \mathrm{~mL} \mathrm{15} \mathrm{Hari} \mathrm{POC}$ & $52,8 \mathrm{cde}$ \\
A8B15 & $8 \mathrm{~mL} \mathrm{15} \mathrm{Hari} \mathrm{POC}$ & $55,1 \mathrm{e}$ \\
\hline
\end{tabular}

Keterangan: Angka yang diikuti oleh huruf yang sama berarti berbeda tidak nyata pada taraf uji

Tabel 8 menunjukkan bahwa perlakuan kombinasi A6B10 $(57,2)$ berbeda tidak nyata dengan perlakuan A8B0 $(45,7)$, A0B5 $(48,6)$, A4B5 $(47,1)$, A6B5 $(55,9)$, A8B5 $(53,1)$, A0B10 $(52,0), \mathrm{A} 4 \mathrm{~B} 10(47,6), \mathrm{A} 8 \mathrm{~B} 10(54,6), \mathrm{A} 4 \mathrm{~B} 15$ (50,8), A6B15 (52,8), dan A8B15 (55,1). Perlakuan interaksi antara dosis dan lama fermentasi POC kulit pisang menunjukkan bahwa pada perlakuan A6B10 (6 ml 10 Hari $\mathrm{POC} / 100 \mathrm{ml}$ air) diperoleh nilai tertinggi.

\section{Berat Bering}

Pengukuran berat bering dilakukan pada minggu terakhir yakni 31 hari setelah tanam (HST) dengan cara menimbang tanaman yang sudah dioven selama 24 jam menggunakan timbangan analitik. Hasil uji DMRT 5\% dosis dan lama fermentasi POC kulit pisang terhadap berat kering bayam merah disajikkan pada Tabel 9.

Tabel 9. Hasil Uji Perbedaan antar Kombinasi terhadap Berat Basah Bayam Merah

\begin{tabular}{cc}
\hline Perlakuan Dosis & Hasil Uji DMRT \\
\hline A0 & $5,22 \mathrm{c}$ \\
A4 & $6,96 \mathrm{~b}$ \\
A6 & $6,91 \mathrm{ab}$ \\
A8 & $7,37 \mathrm{a}$ \\
\hline
\end{tabular}

\begin{tabular}{cc}
\hline Lama Fermentasi & Hasil Uji DMRT \\
\hline B0 & $4,95 \mathrm{~d}$
\end{tabular}

\begin{tabular}{cl} 
B5 & $5,97 \mathrm{c}$ \\
B10 & $7,10 \mathrm{~b}$ \\
B15 & $8,16 \mathrm{a}$ \\
\hline
\end{tabular}

Aplikasi POC kulit pisang pada dosis A8 (8 ml POC/100 ml air) dan B15 (15 hari) menunjukkan hasil paling tinggi darisemua perlakuan dalam penelitian ini dan berbeda nyata dengan perlakuan lainnya (Tabel 9). Berdasarkan hasil tersebut, dosis A8 dan lama fermentasi B15 merupakan perlakuan terbaik pada penelitian ini. Hasil uji perbedaan antar kombinasi terhadap berat kering tanaman bayam merah disajikan pada Tabel 10.

Tabel 10. Hasil Uji Perbedaan antar Kombinasi terhadap Berat Bering Bayam Merah

\begin{tabular}{|c|c|c|}
\hline Kode & $\begin{array}{l}\text { Dosis Perlakuan } \\
\text { (per } 100 \text { ml air) }\end{array}$ & $\begin{array}{c}\text { Rata-Rata Berat Basah } \\
(\text { gr) }\end{array}$ \\
\hline A0B0 & $0 \mathrm{~mL} 0$ Hari POC & $3,6 \mathrm{a}$ \\
\hline $\mathrm{A} 4 \mathrm{~B} 0$ & 4 mL 0 Hari POC/ & $4,9 \mathrm{a}$ \\
\hline A6B0 & 6 mL 0 Hari POC & $5,0 \mathrm{~b}$ \\
\hline A8B0 & $8 \mathrm{~mL} 0$ Hari POC & $6,1 \mathrm{c}$ \\
\hline A0B5 & $0 \mathrm{~mL} 5$ Hari POC & $4,9 \mathrm{~b}$ \\
\hline A4B5 & 4 mL 5 Hari POC & $6,9 \mathrm{~cd}$ \\
\hline A6B5 & 6 mL 5 Hari POC & 6,9 cde \\
\hline A8B5 & 8 mL 5 Hari POC & 7,0 cde \\
\hline $\mathrm{A} 0 \mathrm{~B} 10$ & $0 \mathrm{~mL} 10$ Hari POC & $5,9 \mathrm{bc}$ \\
\hline A4B 10 & 4 mL 10 Hari POC & $7,4 \mathrm{de}$ \\
\hline A6B 10 & $6 \mathrm{~mL} 10$ Hari POC & $7,9 \mathrm{e}$ \\
\hline A8B 10 & $8 \mathrm{~mL} 10$ Hari POC & $9,0 \mathrm{f}$ \\
\hline $\mathrm{A} 0 \mathrm{~B} 15$ & $0 \mathrm{~mL} 15$ Hari POC & $6,3 \mathrm{c}$ \\
\hline A4B15 & 4 mL 15 Hari POC & $9,4 \mathrm{f}$ \\
\hline A6B 15 & 6 mL 15 Hari POC & $9,5 \mathrm{f}$ \\
\hline A8B15 & $8 \mathrm{~mL} 15$ Hari POC & $9,1 \mathrm{f}$ \\
\hline
\end{tabular}

Keterangan: Angka yang diikuti oleh huruf yang sama berarti berbeda tidak nyata pada taraf uji

Tabel 10 menunjukkan bahwa perlakuan kombinasi A6B15 dengan nilai 9,5 tidak berbeda nyata dengan A4B15 dengan nilai 9,4, A8B15 dengan nilai 9,1 dan A8B10 dengan nilai 9,0. Mengacu pada Hanafiah (2016) maka perlakuan terbaik pada kombinasi tersebut adalah A8B10 (8 $\mathrm{ml} 10$ Hari POC/100 ml air).

\section{Pengaruh dosis POC kulit pisang terhadap pertumbuhan tanaman bayam merah}

Perlakuan dosis POC kulit pisang berpengaruh terhadap semua parameter pertumbuhan. Terdapat perbedaan nyata antar perlakuan A0 (0 ml POC/100 ml air), A4 (4 ml $\mathrm{POC} / 100 \mathrm{ml}$ air), A6 (6 ml POC/100 ml air), dan A8 $(8 \mathrm{ml} \mathrm{POC} / 100 \mathrm{ml}$ air) terhadap parameter tinggi tanaman, jumlah daun, luas daun, berat basah dan berat kering. Hal ini menunjukkan bahwa terdapat minimal satu perlakuan dosis 
POC kulit pisang pada parameter tersebut yang berbeda nyata.

Perlakuan dosis A8 (8 $\mathrm{ml} \mathrm{POC/100} \mathrm{ml} \mathrm{air)}$ dan dosis A6 (6 ml POC/100 ml air) memberikan hasil terbaik. Aplikasi dosis $8 \mathrm{ml}$ POC/100 ml air menunjukkan hasil paling baik pada parameter tinggi tanaman dan jumlah daun. Perlakuan terbaik pada parameter luas daun, berat basah dan berat kering adalah dosis A6 $(6 \mathrm{ml} \mathrm{POC} / 100 \mathrm{ml}$ air). Hal ini disebabkan karena pada dosis A8 (8 $\mathrm{ml} \mathrm{POC/100} \mathrm{ml} \mathrm{air)} \mathrm{dan} \mathrm{A6} \mathrm{(6} \mathrm{ml} \mathrm{POC/100} \mathrm{ml}$ air) kandungan unsur hara $\mathrm{N}, \mathrm{P}$ dan $\mathrm{K}$ yang terdapat pada POC kulit pisang sangat tepat dalam merangsang pertumbuhan bayam merah. Menurut Manis, et al. (2017) pupuk cair kulit pisang mengandung unsur $\mathrm{N}, \mathrm{P}$, dan $\mathrm{K}$ yang diperlukan untuk pertumbuhan tanaman bayam merah. Hal ini diperkuat hasil penelitian Nasution (2014) bahwa pupuk organik cair kulit pisang kepok mengandung unsur hara seperti Corganik $(0,55 \%), \mathrm{N}(0,78 \%), \mathrm{P} 2 \mathrm{O} 5(0,043 \%)$, $\mathrm{K} 2 \mathrm{O}(1,137 \%)$ dan $\mathrm{C} / \mathrm{N}(3,06 \%)$, yang cukup esensial bagi tanaman. Menurut Machrodania (2015), kandungan unsur hara N, P, K yang dilaporkan Nasution (2014) tersebut termasuk dalam kategori sangat tinggi, yaitu $\mathrm{N}>0,75 \%$, $\mathrm{P}>0,035 \%$, dan $\mathrm{K}>0,06$ sehingga berperan sangat penting dalam pertumbuhan tanaman bayam merah.

Pertumbuhan tanaman bayam merah sangat erat kaitannya dengan kombinasi unsur hara makro. Diduga kandungan nitrogen POC kulit pisang pada dosis A8 (8 ml POC/100 ml air) dan A6 (6 ml POC/100 ml air) sangat efektif dalam merangsang pertumbuhan tanaman karena dapat memicu terjadinya peristiwa pembelahan dan perpanjangan sel. Menurut Hernosa, et al. (2015) penambahan bahan organik yang mengandung nitrogen dalam jumlah yang tepat akan mempengaruhi kadar nitrogen total yang dapat membantu mengaktifkan sel-sel tanaman yang berhubungan dengan pertumbuhan seperti tinggi tanaman, jumlah daun, dan luas daun. Selain nitrogen, unsur hara yang berperan dalam meningkatkan luas daun adalah fosfor. Hernosa, et al. (2015) menyatakan bahwa unsur fosfor (P) sangat berperan dalam proses respirasi dan fotosintesis sehingga mampu mendorong pertumbuhan tanaman yaitu luas daun. Tinggi tanaman, jumlah daun, dan luas daun pada akhirnya akan mempengaruhi berat basah tanaman. Selain itu juga, peningkatan proses fotosintesis juga dipengaruhi oleh unsur hara $\mathrm{P}$, adanya peningkatan tersebut dapat mengakibatkan peningkatan hasil fotosintesis berupa senyawasenyawa organik yang akan ditranslokasikan ke seluruh organ tanaman dan berpengaruh terhadap berat kering tanaman (Machrodania, et al., 2015).

\section{Pengaruh lama fermentasi POC kulit pisang terhadap parameter pertumbuhan tanaman bayam merah}

Perlakuan lama fermentasi POC kulit pisang berpengaruh terhadap semua parameter pertumbuhan. Terdapat perbedaan nyata antar perlakuan B0 (0 hari), B5 (5 hari), B10 (10 hari) dan B15 (15 hari) terhadap parameter tinggi tanaman, jumlah daun, luas daun, berat basah dan berat kering. Hal ini menunjukkan bahwa terdapat minimal satu perlakuan lama fermentasi POC kulit pisang pada parameter tersebut yang berbeda nyata.

Perlakuan lama fermentasi B10 (10 hari) dan B15 (15 hari) memberikan hasil terbaik. Aplikasi lama fermentasi 15 hari menunjukkan hasil paling baik pada parameter tinggi tanaman, berat basah dan berat kering. Perlakuan terbaik pada parameter luas daun dan jumlah daun adalah lama fermentasi B10 (10 hari). Hal ini disebabkan karena lama fermentasi POC kulit pisang pada hari ke-10 dan ke-15 mengandung komposisi unsur hara $\mathrm{N}, \mathrm{P}$ dan $\mathrm{K}$ yang sangat tepat dalam merangsang pertumbuhan tinggi tanaman, jumlah daun, luas daun, berat basah dan berat kering tanaman bayam merah. Menurut Wijaksono, et al. (2016) perlakuan lama fermentasi merupakan salah satu faktor yang dapat mempengaruhi ketersediaan unsur hara dalam pembuatan POC kulit pisang, dimana selama rentang waktu fermentasi terjadi transformasi yang dapat meningkatkan bahkan menghilangkan komposisi atau kandungan unsur hara yang terkandung dalam POC. Kandungan unsur hara yang banyak pada lama fermentasi 10 hari dan 15 hari tersebut diduga karena mikroorganisme yang berperan dalam POC berada pada fase log yaitu mikroorganisme mengalami pertumbuhan dan perkembangan secara cepat sesuai dengan hasil yang dipaparkan Nursyam (2011) dan Manis, et al. (2017).

Pengaruh interaksi antara dosis dan lama 


\section{fermentasi POC kulit pisang terhadap parameter pertumbuhan tanaman bayam merah}

Perlakuan interaksi dosis dan lama fermentasi POC kulit pisang berpengaruh terhadap hampir semua parameter pertumbuhan. Terdapat perbedaan nyata antar interaksi perlakuan dosis dan lama fermentasi terhadap parameter tinggi tanaman, jumlah daun, berat basah, dan berat kering, sedangkan pada parameter luas daun tidak menunjukkan adanya interaksi. Perlakuan interkasi yang berbeda nyata menunjukkan bahwa masing-masing aras (dosis dan lama fermentasi) saling berkaitan, masingmasing faktor tidak berdiri sendiri-sendiri dalam mempengaruhi parameter tinggi tanaman, jumlah daun, berat basah, dan berat kering. Namun kondisi sebaliknya terjadi pada luas daun, dimana masing-masing aras yang digabungkan tidak saling mempengaruhi, sehingga masingmasing aras pada perlakuan ini berdiri sendirisendiri dalam mempengaruhi pertumbuhan luas daun.

Ada dua perlakuan terbaik terhadap parameter pertumbuhan pada kombinasi antara dosis dan lama fermentasi. Perlakuan A8B15 memberikan hasil terbaik terhadap tinggi tanaman dan berat basah, sedangkan jumlah daun dan berat kering diperoleh pada perlakuan A8B10. Perlakuan A8B15 dan A8B10 memberikan hasil terbaik bagi pertumbuhan tanaman bayam karena unsur-unsur hara yang terkandung dalam perlakuan kombinasi tersebut berada pada jumlah optimum yang dibutuhkan untuk pertumbuhan. Menurut Tenaya (2015) adanya interaksi yang saling mendukung antara dosis dengan lama fermentasi dikarenakan jumlah mikroba dan kandungan unsur hara pada POC meningkat sehingga dengan memberikan dosis yang optimum maka mampu meningkatkan pertumbuhan tanaman bayam merah. Selain itu, faktor lingkungan seperti $\mathrm{pH}$ dan suhu berada dalam kondisi yang optimum dalam menunjang pertumbuhan (Gambar 1 dan Gambar 2).

\section{Kesimpulan}

Berdasarkan hasil penelitian dan pembahasan, maka dapat disimpulkan bahwa: (1) Pemberian pupuk organik cair kulit pisang pada dosis $4 \mathrm{ml} \mathrm{POC} / 100 \mathrm{ml}$ air, $6 \mathrm{ml} \mathrm{POC} / 100 \mathrm{ml}$ air, dan $8 \mathrm{ml} \mathrm{POC} / 100 \mathrm{ml}$ air pada bayam merah
(Amaranthus tricolor L.) berpengaruh terhadap tinggi tanaman, jumlah daun, luas daun, berat basah, dan berat kering, (2) Pemberian pupuk organik cair kulit pisang dengan dosis $8 \mathrm{~mL} / 100$ $\mathrm{mL}$ air menunjukkan hasil paling baik pada parameter tinggi tanaman dan jumlah daun, sedangkan perlakuan terbaik pada parameter luas daun, berat basah dan berat kering adalah pada dosis $6 \mathrm{ml} \mathrm{POC/100} \mathrm{ml} \mathrm{air,} \mathrm{(3)} \mathrm{Pemberian} \mathrm{pupuk}$ organik cair kulit pisang dengan lama fermentasi 5 hari, 10 hari, dan 15 hari berpengaruh terhadap tinggi tanaman, jumlah daun, luas daun, berat basah, dan berat kering, (4) Pemberian pupuk organik cair kulit pisang dengan lama fermentasi 15 hari menunjukkan hasil paling baik pada tinggi tanaman, berat basah dan berat kering, sedangkan lama fermentasi 10 hari paling efektif terhadap luas daun dan jumlah daun, (5) Permberian perlakuan kombinasi antara dosis dan lama fermentasi pupuk organik cair kulit pisang memiliki interaksi nyata terhadap tinggi tanaman, jumlah daun, berat basah dan berat kering, kecuali pada parameter luas daun, dan (6) Perlakuan kombinasi terbaik diperoleh pada $8 \mathrm{ml}$ 15 Hari POC/100 ml air terhadap tinggi tanaman dan berat basah, sedangkan terhadap jumlah daun dan berat kering pada $8 \mathrm{ml} 10$ Hari POC/100 ml air.

\section{Ucapan Terima Kasih}

Penulis mengucapkan terima kasih kepada semua pihak yang telah membantu baik moril maupun materil sehingga terselesaikannya penelitian dan paper ini.

\section{Referensi}

Hadisuwitno, S. (2012). Membuat Pupuk Kompos Cair. Jakarta: AgroMedia Pustaka.

Hartini, S., Sholihah, S. M., \& Manshur, E. (2019). Pengaruh Konsentrasi Urin Kelinci Terhadap Pertumbuhan dan Hasil Bayam Merah (Amaranthus gangeticus voss). Jurnal Ilmiah Respati, 10(1), 20-27. http://ejournal.urindo.ac.id/index.php/pert a nian/article/viewFile/355/306. 
Hanafiah, K. A. (2016). Rancangan Percobaan Teori dan Aplikasi (Ed. Ketiga). Jakarta: PT. Raja Grafindo Persada.

Hernosa, S. P., Yudi T. \& Eko W. (2015). Pengaruh Pemberian Pupuk Organik Cair Kulit Pisang Terhadap Pertumbuhan Dan Produksi Tanaman Sawi (Brassica juncea). Jurnal Agroplasma, 2(2). 15-21. https://jurnal.ulb.ac.id/index.php/agro/arti $\underline{\text { cle/view/138 }}$

Irwan, A. W., \& Wicaksono, F. Y. (2017). Perbandingan Pengukuran Luas Daun Kedelai dengan Metode Gravimetri, Regresi dan Scanner. Kultivasi, 16(3), 425429. https://doi.org/10.24198/kultivasi.v16i3.1 $\underline{4448}$

Kurniawati, H. Y., Karyanto, A., \& Rugayah. (2015). Pengaruh Pemberian Pupuk Organik Cair dan Dosis Pupuk Npk (15:15:15) Terhadap Pertumbuhan dan Produksi Tanaman Mentimun (Cucumis sativus L.). Jurnal Agrotek Tropika, 3(1), 30-35.

http://jurnal.fp.unila.ac.id/index.php/JA/ar ticle/view/1894

Lingga, P. \& Marsono (2008). Petunjuk Penggunaan Pupuk. Jakarta: Penebar Swadaya.

Machrodania, Yuliani \& Evie R. (2015). Pemanfaatan Pupuk Organik Cair Berbahan Baku Kulit Pisang, Kulit Telur dan Gracillaria gigas terhadap Pertumbuhan Tanaman Kedelai var Anjasmoro. Jurnal LanteraBio, 4(3). 168173.

https://jurnalmahasiswa.unesa.ac.id/index .php/lenterabio/article/view/13255

Manis, I., Supriadi \& Irwan S. (2017). Utilization of Banana Peel Waste as an Organic Liquid Fertilizer and its Aplication on Growth of Swamp Cabbage Land (Ipomea reptans Poir). Journal Akademika Kim, 6(4).

219-226. http://jurnal.untad.ac.id/jurnal/index.php/J AK/article/view/9452.
Marjenah., Wawan K., Ida N., Keren H. M. S., \& Retno P. E. (2017). Pemanfaatan Limbah Kulit Buah-Buahan sebagai Bahan Baku Pembuatan Pupuk Organik Cair. Jurnal Hutan Tropika, 1(2). 120-127. http://ejournals.unmul.ac.id/index.php/UJ HT/article/view/800.

Nasution, F. J., Lisa M. \& Meiriani (2014). Aplikasi Pupuk Organik Padat dan Cair dari Kulit Pisang Kepok untuk Pertumbuhan dan Produksi Sawi (Brassica juncea L.). Jurnal Online Agroekoteknologi, 2(3). 1029-1037.

Nasrun, Jalaludin \& Herawati (2016). Pemanfaatan Limbah Kulit Pisang Barangan sebagai Bahan Pembuatan Pupuk Cair. Jurnal Teknologi Kimia Unimal, 5(2). 19-26. https://ojs.unimal.ac.id/jtk/article/view/86

Nur, T., Ahmad R. N., \& Muthia E. (2016). Pembuatan Pupuk Organik Cair dari Sampah Organik Rumah Tangga dengan Penambahan Bioaktivator EM E. Jurnal Konversi, $\quad 5(2) . \quad 5-12$. https://media.neliti.com/media/publicatio ns/107634-ID-none.pdf.

Nursyam, H. (2011). Pengolahan Sosis Fermentasi Ikan Tuna (Thunnus Sp.) Menggunakan Kultur Starter Lactobacillus plantarum terhadap Nilai pH, Total Asam, N-Total, dan Namino. Jurnal Ilmiah Perikanan dan Kelautan, 3(2). 221-228. https://www.ejournal.unair.ac.id/JIPK/article/view/1160 $\underline{9}$.

Pangaribuan, D. H., Yohannes C. G., Lucky P. S., \& Hairani F. (2017). Aplikasi Pupuk Organik Cair dan Pupuk Anorganik terhadap Pertumbuhan, Produksi, dan Kualitas Pascapanen Jagung Manis (Zea mays var. saccharata Sturt.). Jurnal Hortikultura Indonesia, 8(1). 59-67. https://jurnal.ipb.ac.id/index.php/jhi/articl e/view/17491. 
Putra, B. W. R. I. H., \& Rhenny R. (2019). Pembuatan Pupuk Organik Cair dari Limbah Buah dengan Penambahan Bioaktivator EM4. Jurnal Sains dan Teknologi Lingkungan, 11(1). 44-56. https://journal.uii.ac.id/JSTL/article/view/ $\underline{13201 .}$.

Raksun, A. (2018). Pengaruh Bokashi Terhadap Produksi Padi (Oryza sativa L.). Jurnal Penelitian Pendidikan IPA, 4(1). 64-67. http://www.jppipa.unram.ac.id/index.php/ jppipa/article/view/107.

Raksun, A., Mahrus \& I. G. Mertha (2020). Pertumbuhan Tomat (Solanum lycopersicum Mill) pada Keragaman Tipe Mulsa dan Dosis Pupuk Organik. Jurnal Biologi Tropis, 20(1). 40-45. https://jurnalfkip.unram.ac.id/index.php/J BT/article/view/1420.

Rangkuti, N. P. J., Mukarlina \& Rahmawati (2017). Pertumbuhan Bayam Merah (Amaranthus tricolotr L.) yang diberi Pupuk Kompos Kotoran Kambing dengan Dekomposer Trichoderma harzianum. Jurnal PROTOBIONT, 6(2). 18-25. https://jurnal.untan.ac.id/index.php/jprb/a rticle/view/20797.

Rinaldi, T., Cik Z., \& Safruddin (2018). Growth Response and Yield of Red Spinach (Alternanthera Amoena L). Against Organic Chicken Dung Fertilizer and Cow Urine Fermented Application. Journal Agricultural Research, 14(1). 51-59. http://jurnal.una.ac.id/index.php/jb/article /view/329.

Syarif (2020). International Conference on Food and Bio-Industry 2019 IOP Conf. Series: Earth and Environmental Science 443 (2020) $012021 \quad$ IOP Publishing doi:10.1088/1755-1315/443/1/012021

Susanto, R. (2002). Penerapan Pertanian Organik. Yogyakarta: Kanisius.

Susetya, D. (2012). Panduan Lengkap Membuat Pupuk Organik. Jakarta: Baru Press.
Tenaya, I. M. N. (2015). Pengaruh Interaksi dan Nilai Interaksi pada Percobaan Faktorial (Review). Jurnal Agrotrop, 5(1). 9-20. https://ojs.unud.ac.id/index.php/agrotrop/ article/view/18369.

Wijaksono, R. A., Rijadi S., \& Bambang U. (2016). Pengaruh Lama Fermentasi pada Kualitas Pupuk Kandang Kambing. Jurnal Agro Industri Perkebunan, 4(2). 88-96. https://jurnal.polinela.ac.id/index.php/AIP /article/view/50. 